\title{
Ipsilateral Simultaneous Shoulder and Elbow Dislocation: A Case Report
}

\author{
İpsilateral Travmatik Omuz ve Dirsek Çıkığı: Olgu Sunumu
}

\author{
Ahmet iMERCi, Mert KUMBARACI, Mustafa INCESU, Ahmet SAVRAN, Levent KARAPINAR \\ Department of Orthopaedics and Traumatology, Izmir-Tepecik Training and Research Hospital, Izmir, Turkey
}

\section{SUMMARY}

Ipsilateral dislocation of the shoulder and elbow joints is a rare and complex injury. Only six patients have been reported in the international literature with ipsilateral dislocation of the shoulder and elbow. Here, we reported a 48-year-old woman who suffered ipsilateral shoulder and elbow dislocation. The patient first presented to a regional hospital and the radiographs taken following the initial evaluation revealed posterolateral dislocation of right elbow. The reduction of the dislocated elbow was performed at that facility. However, since no radiographic examination of the injured shoulder had been carried out, the dislocation injury of the shoulder was missed. Three days later the patient presented to Tepecik Training and Research Hospital Emergency Department (Izmir-Turkey), complaining of shoulder pain. Radiographs showed the missed anterior dislocation of right shoulder, which had been reduced under general anaesthesia. At final follow-up, 2.5 years later, the elbow and the shoulder were pain free and had full range of motion. Following a high energy trauma in upper extremities, radiographic examination of the shoulder, elbow and wrists must be performed in case of suspicion.

Key words: Elbow; ipsilateral dislocation; shoulder.

\section{ÖZET}

Ipsilateral travmatik omuz ve dirsek çıkığı nadir görülen, kompleks bir yaralanmadır. Uluslararası literatürde ipsilateral travmatik omuz ve dirsek çıkıklı sadece altı hasta rapor edilmiştir. Bu olgu sunumunda, 48 yaşında ipsilateral travmatik omuz ve dirsek çıkığı olgusu sunuldu. Hastanın önce başka bir hastaneye başvurduğu ve kazadan hemen sonra çekilen grafilerinde sağ dirseğin posterolateral çıkığı saptandığı ve çığın redükte edildiği öğrenildi. Sağ omuz grafilerinin çekilmemiş olması nedeniyle omuz çıkığı gözden kaçmıştı. Yaralanmanın üçüncü gününde hasta ek yeni travma olmaksızın omuz ağrısı şikayeti ile İmir Tepecik Eğitim ve Araştırma Hastanesi Acil Servisine başvurdu. Çekilen grafilerinde atlanmış sağ omuz çıkığı saptandı ve genel anestezi altında redükte edildi. Travmadan 2.5 yıl sonra hastanın yapılan son kontrollerinde sağ omuz ve dirseğin ağrısız şekilde tam hareket genişliğine sahip olduğu izlendi. Üst ekstremitede yüksek enerjili travmayı takiben, şüphe duyulan hastalarda, aynı taraftaki dirsek, omuz ve elbileği gibi komşu eklemlerin radyografik kontrolleri yapılmalıdır.

Anahtar sözcükler: Dirsek; ipsilateral çıkık; omuz.

\section{Introduction}

In adults, the elbow is the second most frequently dislocated major joint, after the shoulder. ${ }^{[1,2]}$ More than $90 \%$ of all elbow dislocations are posterior dislocations. ${ }^{[2]}$ But, a major joint dislocation of such as shoulder, elbow, hip or knee associated with the dislocation of the adjacent proximal or distal joints is a rare condition and mostly occurs as a result of complex injury. ${ }^{[3]}$ During the last 30 years, only 6 patients have been reported in the literature ${ }^{[3-8]}$ to suffer such injuries. The rarity of this injury may cause the diagnosis to be delayed or missed. ${ }^{[4-6]}$

The aim of this study was to report such a case, to discuss its

Submitted (Geliş tarihi): January 26, 2011 Accepted (Kabul tarihi): March 18, 2011

Correspondence (iletişim): Levent Karapinar, M.D. Menderes Cad., No: 46/1, Buca 35140 İzmir, Turkey

e-mail (e-posta): Ikarapinar@yahoo.com 
diagnostic pitfalls, mechanism, management and possible complications, ways to avoid a missed or delayed diagnosis and to review the literature.

\section{Case Report}

A 48-year-old obese woman referred to a regional hospital with right arm pain and elbow deformity following a fall down a flight of stairs two hours prior. On presentation to the emergency department, she had been supporting her right upper extremity with her left hand and forearm in the position of comfort. Initial inspection had revealed a gross posterior deformity of the elbow joint. Radiographs were ordered only for the right and they showed posterolateral dislocation of elbow. The joint had been reduced under general anesthesia by an orthopaedic surgeon. The elbow joint had been immobilized at $90^{\circ}$ of flexion. Anteroposterior and lateral radiographs had confirmed the reduction. The elbow had been put in a cast in $90^{\circ}$ of flexion with the forearm slightly supinated for 2 days.

On the third day she presented to Tepecik Training and Research Hospital Emergency Department with complaining of pain and numbness on her right arm and shoulder. She was also complaining of soft tissue swelling on her right elbow with hypoesthesia on her lateral part of right arm and pain at her right shoulder. The patient experienced pain whenever her shoulder was moved and had tenderness all over the shoulder joint. She did not present apolet sign. Ipsilateral radiographs of shoulder and elbow joints were obtained.

The radiograph of the shoulder revealed anterior dislocation and a fracture of the greater tuberosity associated with it. Anterior dislocation of shoulder was treated by closed reduction under general anesthesia using Kocher's method. The elbow was tested for stability and was found to be stable. Long arm cast immobilization was applied. After two weeks, the cast was removed and her shoulder was protected in a sling while she performed limited pendulum exercises for the first six weeks. At 3rd-week of follow-up, the patient had regained a flexion-extension range of motion from $40^{\circ}$ to $110^{\circ}$. At sixth month follow-up, the elbow and shoulder were painless with full range of motion, there was no hypoesthesia on her right arm and the patient was advised to resume her normal activities. At final follow-up 2.5 years later, the elbow and the shoulder were pain-free even when fully stretched. The varus-valgus stress of the elbow joint revealed no signs of instability. Neurovascular examination revealed no deficits (Figure 1).

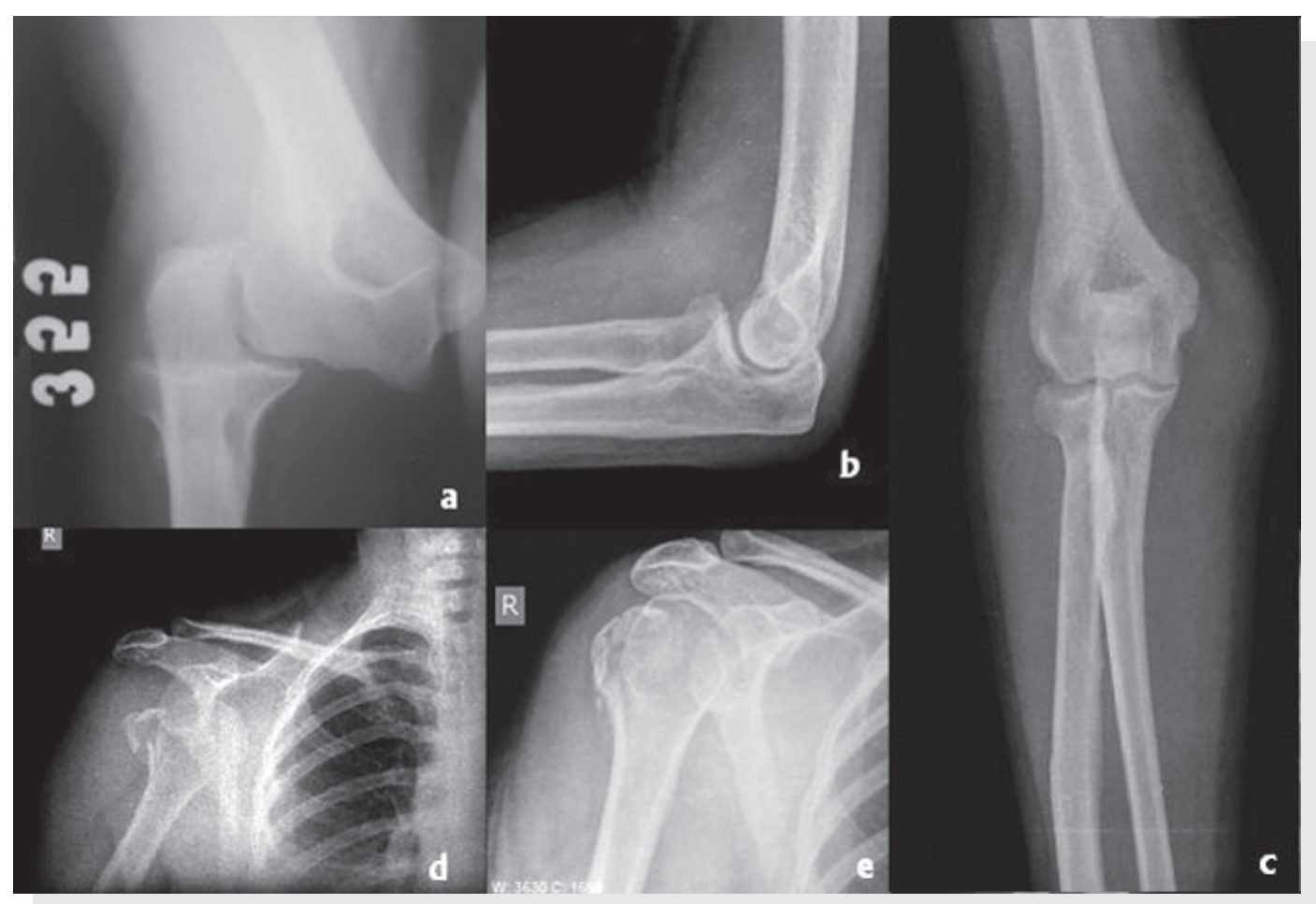

Figure 1. Radiograph of the right elbow of the patient at the time of presentation at first hospital. (a) Lateral (b) and anteroposterior (c) radiographs of reduced right elbow dislocation, and anteroposterior radiograph of the fracture dislocation of right shoulder before (d) and after (e) the closed reduction at the second hospital. 
Table 1. Patients reported in the international literature with ipsilateral dislocation of the shoulder and elbow

\begin{tabular}{|c|c|c|c|c|c|c|}
\hline No & Author & Year & Age/Gender & Cause of injury & Management & Associated fractures \\
\hline 1 & Suman & 1981 & $31 / M$ & Traffic accident & Closed reduction & Facial injury \\
\hline 2 & Ali & 1998 & $33 / F$ & Fall & Closed reduction & Displaced fracture of the radial head \\
\hline 3 & Khan and Mirdad & 2001 & $35 / M$ & Traffic accident & Closed reduction & Displaced fracture of greater tuberosity \\
\hline 4 & Essoh et al. & 2005 & $31 / \mathrm{M}$ & Fall & Closed reduction & No fracture \\
\hline 5 & Kerimoğlu et al. & 2006 & $50 / F$ & Pedestrian hit by a car & $\begin{array}{l}\text { Closed reduction }+ \\
\mathrm{K} \text { wires fixation }\end{array}$ & Contralateral comminuted humeral fracture \\
\hline 6 & Inan et al. & 2008 & $27 / M$ & Work accident & Closed reduction & $\begin{array}{l}\text { Open midshaft fracture of humerus + } \\
\text { Displaced fracture of greater tuberosity }\end{array}$ \\
\hline 7 & Our patient's report & 2010 & $48 / F$ & Fall & Closed reduction & Displaced fracture of greater tuberosity \\
\hline
\end{tabular}

\section{Discussion}

Ipsilateral dislocation of shoulder and elbow joints is a rarely seen injury and it can easily be missed. ${ }^{[4-6]}$ Suman first reported a case of ipsilateral dislocation of the shoulder and elbow in 1981 in which a 31-year-old man involved in a road traffic accident while the influence of alcohol and suffered an injury. ${ }^{[4]}$ The shoulder dislocation can be initially missed on admission owing to the marked swelling and severe pain located at the elbow. ${ }^{[5,6]}$ Meanwhile, in obese patients the shoulder dislocation may not result in a significant loss of deltoid contour. ${ }^{[5]}$ Similarly our patient was also obese and there was no apolet sign seen. ${ }^{[9]}$

A review of literature revealed six reports of ipsilateral dislocation of the shoulder and elbow, and in four of these cases, the dislocation injury was also associated with ipsilateral fractures (Table 1). The brachial plexus and axillary artery lie immediately anterior, inferior, and medial to the gleno-humeral joint. It is not surprising therefore that neurovascular injury frequently accompany anterior gleno-humeral dislocations. ${ }^{[10]}$ Associated fracture of the greater tuberosity occurs in 15\% of the anterior dislocation cases and indicates an associated rotator cuff tears, ${ }^{[11,12]}$ which can cause long-term instability and functional impairment if the greater tuberosity fragment is not anatomically reduced. ${ }^{[13]}$ In our patient, greater tuberosity was anatomically reduced, she had excellent result at 2.5-years follow-up.

Although, this complex injury results from severe trauma as falling down a flight of stairs, ${ }^{[5,7]}$ the mechanism of this kind of injury is difficult to define, but a sudden enormous axial loading of the humerus at the flexed elbow with the shoulder in a slightly abducted and extanded position may be prerequisite for the simultaneous dislocation of the shoulder and elbow.

Urgent joint reduction is indicated if evidence of any clinical or radiographic diagnosis of acute elbow or shoulder dislocation is present. Orthopedic consultation should be con- sidered. As there is a greater awareness of anterior shoulder dislocations for trauma patients, it could be reasonable to assume that there may be a higher incidence of delayed diagnosis of such an injury following a presentation with an indirect complaint, such as a seizure. ${ }^{[14]}$ The unusual presentation combined with the patient's post-ictal discomfort and drowsy state may potentially delay the diagnosis. As this could affect the prognosis, early recognition is significant because of the risk of neurovascular or cartiloginous complications. The critical element in the assessment of any injured joint is the standard physical examination of adjacent bones and joints. Areas of abrasion, contusion, or swelling should be X-rayed to decrease the potential for a missed injury. Closed reduction of a neglected anterior shoulder dislocation can be performed only up to six weeks post injury. After this period the danger of an iatrogenic fracture or neurovascular damage raises too high and operative procedures shall be followed. ${ }^{[15]}$

\section{Conflict of Interest}

The Author(s) declare(s) no conflict of interest related to this work.

\section{Conclusion}

Ipsilateral shoulder and elbow dislocation is a rare injury, however emergency physicians must be familiar with this clinical situation. Careful clinical and radiographic examination at the time of initial presentation could decrease the number of missed dislocations. Following a high energy trauma in upper extremity, radiographic evaluation of the shoulder, elbow and wrist ipsilaterally should be performed to rule out injuries to the entire length of the extremity.

\section{References}

1. Dodson CC, Cordasco FA. Anterior glenohumeral joint dislocations. Orthop Clin North Am 2008;39:507-18, vii. 
2. Josefsson PO, Nilsson BE. Incidence of elbow dislocation. Acta Orthop Scand 1986;57:537-8.

3. Inan $U$, Cevik AA, Omeroğlu H. Open humerus shaft fracture with ipsilateral anterior shoulder fracture-dislocation and posterior elbow dislocation: a case report. J Trauma 2008;64:1383-6.

4. Suman RK. Simultaneous dislocations of the shoulder and the elbow. Injury 1981;12:438.

5. Ali FM, Krishnan S, Farhan MJ. A case of ipsilateral shoulder and elbow dislocation: an easily missed injury. J Accid Emerg Med 1998;15:198.

6. Khan MR, Mirdad TM. Ipsilateral dislocation of the shoulder and elbow. Saudi Med J 2001;22:1019-21.

7. Essoh JBS, Kodo M, Traoré A, Lambin Y. Ipsilateral dislocation of the shoulder and elbow: A case report. Nigerian journal of surgical research. 2005;7:319-320.

8. Kerimoglu S, Turgutoglu O, Aynaci O, Turhan AU. Ipsilateral dislocation of the shoulder and elbow joints with contralateral comminuted humeral fracture. Saudi Med J 2006;27:190811.
9. Chen $\mathrm{CH}$, Lai PL, Niu CC, Chen WJ, Shih CH. Simultaneous anterior dislocation of the shoulder and fracture of the ipsilateral humeral shaft. Two case reports. Int Orthop 1998;22:65-7.

10. Sonnabend $\mathrm{DH}$. Treatment of primary anterior shoulder dislocation in patients older than 40 years of age. Conservative versus operative. Clin Orthop Relat Res 1994:74-7.

11. Dinopoulos HT, Giannoudis PV, Smith RM, Matthews SJ. Bilateral anterior shoulder fracture-dislocation. A case report and a review of the literature. Int Orthop 1999;23:128-30.

12. Ferkel RD, Hedley AK, Eckardt JJ. Anterior fracture-dislocations of the shoulder: pitfalls in treatment. J Trauma 1984;24:363-7.

13. Neer CS 2nd. Displaced proximal humeral fractures. I. Classification and evaluation. J Bone Joint Surg [Am] 1970;52:107789.

14. Nagi ON, Dhillon MS. Bilateral anterior fracture dislocation of the shoulders. J Orthop Trauma 1990;4(1):93-5.

15. Solomon L, Warwick D, Nayagam S. Injuries of the shoulder, upper arm and elbow. In: Solomon L, Warwick D, Nayagam $\mathrm{S}$, editors. Apleys system of orthopaedics and fractures. London: Arnold; 2001. p. 587-9. 